\title{
The Relatioship between Plant Density and Microclimate and Nutmeg (Myristica fragrans Houtt) Production in Nutmeg and Coconut Mixed-Planting System in Wakatobi District in Indonesia
}

\author{
Abdul Madiki ${ }^{1}$, Bambang Guritno ${ }^{2}$, Syekhfani ${ }^{3} \&$ Nurul Aini $^{2}$ \\ ${ }^{1}$ Department of Agrotechnology, Faculty of Agriculture, Halu Oleo University, Kendari, Indonesia \\ ${ }^{2}$ Department of Agronomy, Faculty of Agriculture, Brawijaya University, Malang, Indonesia \\ ${ }^{3}$ Department of Soil Science, Faculty of Agriculture, Brawijaya University, Malang, Indonesia \\ Correspondence: Abdul Madiki, Department of Agrotechnology, Faculty of Agriculture, Halu Oleo University, \\ Kendari, Indonesia. E-mail: diki.alyen@gmail.com
}

Received: August 2, 2015 Accepted: September 14, 2015 Online Published: November 15, 2015

doi:10.5539/jas.v7n12p187 URL: http://dx.doi.org/10.5539/jas.v7n12p187

\begin{abstract}
In Wakatobi district nutmeg trees are generally cultivated in mixed planting with coconut. The research employed observation method where sample plants were determined purposively based on intersection of nutmeg and coconut tree crowns; 42 plots of pairs of nearest neighboring plants. In each plot of pair of plants, plant density of nutmeg and coconut was calculated (individually and in total), then microclimate components (solar radiation, temperature and relative humidity) and nutmeg plant characteristics (vegetative and prodution components) were measured. Research results showed that plant density of nutmeg (218 plants ha $\left.{ }^{-1}\right)$ had exceeded its optimum number of population, plant density of coconut 144 plants $^{-1} \mathrm{w}^{-1}$ with relative density ratio of $58: 42 \%$ or nutmeg was more dominant than coconut. Transmitted radiation and temperature below the crown was decreasing, and in contrast, intercepted radiation and relative humidity increased in line with the increased plant density of nutmeg. This condition led to the decrease in sum of fruits, weight of mace, and weight of kernel of individual nutmeg tree. Coconut plant density had non-significant correlation and non-significantly contributed to microclimate and production components of nutmeg. This indicated that the tendency for decreased production of nutmeg is less affected by coconut trees, but more because of shading effect of nutmeg trees due to close distance among them. In other word, there occured intraspecific competition (nutmeg and nutmeg), and not interspecific (nutmeg and coconut). Therefore, coconut can be cultivated in mixed planting with nutmeg through appropriate plant spacing.
\end{abstract}

Keywords: plant density, micro climate, nutmeg, coconut, mixed planting, nutmeg production

\section{Introduction}

Nutmeg (Myristica sp.) is known as native spice plants of Indonesia originated from Banda in Maluku (Krishnamoorthy \& Rema, 2001; Anandaraj et al., 2005). Nutmeg has high economic value because its mace and seed kernel can be used as spice, cosmetic and medicinal materials (Leela, 2008). The edible portion of the fruits can be processed chutney, syrup, and jam.

In Wakatobi District nutmeg is exclusively cultivated in smallholder plantation. In 2008, the size of the farm of nutmeg is about 5 ha (Anonymous, 2009) and in 2013 it had reached the cultivated area of 8 ha (Abdul-Madiki \& Tjokrodingrat, 2013, unpublished). In general, nutmeg is cultivated in mixed planting with coconut, coffee, cocoa, banana, or with forest plants such as Java almond. Here, we investigated nutmeg planted in mix with coconut. Planting spacing of both nutmeg and coconut is irregular. In such condition, plant composition and density will affect canopy structure and microclimate which in turn will determine nutmeg productivity.

Close distance among nutmeg trees in the planting system can make the tree leaves shading each other or nutmeg trees being shaded by coconut trees. This condition may reduce the photosynthetic capacity of the leaves and reduce productivity of individual trees. When plant growth is not constrained by water or nutrients, production is determined by the amount of radiant energy that can be intercepted by leaves (Monteith et al., 1991; Monteith, 1994 in Jose et al., 2004). In this regard, penetration and total interception of lights are only parts of the story; 
what is also important is the distribution of lights on the leaves (Gutschick, 1997). These two statements are closely related to plant composition and density, in particular to mixed planting system of nutmeg and coconut.

Several studies on nutmeg had been done, such as those by Hadad dan Syakir (1992), Hadad et al. (1996), Mazuki et al. (2006; 2008), Wardiana et al. (2008), Wahyuni et al. (2008), Hadad and dan Hamid (2009). However, research on the relationship between plant density, micro climate, and plant characteristics, is lacking, especially in Southeast Sulawesi province and in Wakatobi District. The general objectives of the research was to find out the relationship between plant density and microclimate components and nutmeg plant characteristics. In particular, the research aimed 1) to find out the level of plant density of nutmeg and coconut trees in mixed planting method in Wakatobi District, 2) to find out the effect of plant density of nutmeg and coconut trees on microclimate components and nutmeg tree characteristics, and 3) to get overall picture of the level of competition in the mixed planting system of nutmeg and coconut trees.

\section{Materials and Method}

\subsection{Time and Location}

The research had been done from January to December 2013, in smallholder farming of nutmeg in Wangi-Wangi Subdistrict, Wakatobi District, Southeast Sulawesi Province. Sample farm location was selected purposively based on the planting system applied, namely mixed planting of nutmeg and coconut. The size of nutmeg farm is 3.68 ha.

Research site is located at $184-185 \mathrm{~m}$ above sea level, latitude of $05^{\circ} 17.552^{\prime}-05^{\circ} 17.557^{\prime}$ South and $123^{\circ} 33.612^{\prime}-123^{\circ} 33.623^{\prime}$ East altitude. The area has flat and undulating topography. Based on Schmidt and Ferguson classification, Wangi-Wangi Subdistrict is included in E climate type (fairly dry) with vegetation type of savana forest. Average monthly rainfall during research period was in the range of $12 \mathrm{~mm}$ (October) $-582 \mathrm{~mm}$ (May) with the total annual rainfall of $2706 \mathrm{~mm}$ and the number of rain days of 148 days. Results of soil analysis at the laboratory of Department of Soil Science at Faculty of Agriculture of Brawijaya University showed that soil texture at nutmeg agroecosystem was relatively similar to that beyond nutmeg agroecosystem. The dominant soil texture is silty clay $(44.44 \%)$, followed subsequently by silty clay loam $(31.11 \%)$, silty loam $(15.56 \%)$, and clay $(8.89 \%)$. The soil $\mathrm{pH}$ range is $6.60-7.43$.

\subsection{Sample Plants}

Both nutmeg and coconut are 40 years of age, spreading in the area of approximately \pm 3.68 ha. Nutmeg has an average height ranged 13 to $17 \mathrm{~m}$, stem diameter 19 to $24 \mathrm{~cm}$, and width of the canopy 6 to $9 \mathrm{~m}$. Coconut tree is taller than nutmeg tree, and when the distance between the two is close, coconut will shade nutmeg. Plants samples were determined purposively based on the intersection of crowns of nutmeg $(\mathrm{N})$ and coconut $(\mathrm{C})$. There were 42 of pairs of nearest-neighbor plants as follows: 1 nutmeg/without crown intersection $\left(\mathrm{n}_{1}\right)$, intersection of 1 nutmeg +1 nutmeg $\left(n_{1} n_{1}\right), 1$ nutmeg +1 coconut $\left(n_{1} c_{1}\right), 1$ nutmeg +2 coconut $\left(n_{1} c_{2}\right), 1$ nutmeg +3 coconut $\left(\mathrm{n}_{1} \mathrm{c}_{3}\right), 2$ nutmeg +1 coconut $\left(\mathrm{n}_{2} \mathrm{c}_{1}\right), 2$ nutmeg +2 coconut $\left(\mathrm{n}_{2} \mathrm{c}_{2}\right), 2$ nutmeg +3 coconut $\left(\mathrm{n}_{2} \mathrm{c}_{3}\right), 3$ nutmeg +1 coconut $\left(\mathrm{n}_{3} \mathrm{c}_{1}\right), 3$ nutmeg +2 coconut $\left(\mathrm{n}_{3} \mathrm{c}_{2}\right), 3$ nutmeg +3 coconut $\left(\mathrm{n}_{3} \mathrm{c}_{3}\right), 4$ nutmeg +1 coconut $\left(\mathrm{n}_{4} \mathrm{c}_{1}\right), 4$ nutmeg +2 coconut $\left(\mathrm{n}_{4} \mathrm{c}_{2}\right)$, and 4 nutmeg +3 coconut $\left(\mathrm{n}_{4} \mathrm{c}_{3}\right)$. Each plant pairs was observed in three times of pairs $(14$ of pairs $\mathrm{x} 3=42$ plant pairs).

\subsection{Plant Density}

In each plant system (pair of plants) observation was done on the plant composition and density using Point-Centered Quarter (PCQ) sampling method (May dan Penfound, 1967; Mark \& Esler, 1970; Mitchell, 2010). Sampling point was positioned on sample nutmeg trees, and the distance from the point to the nearest-neighbour trees in each quadrant was calculated for each sampling unit according to species (nutmeg and coconut). For plot 1 nutmeg $\left(\mathrm{n}_{1}\right)$, nearest neighbor trees in each quadrant were also recorded.

Measurement results of the distance of the four neighboring trees from sampling point in each quadrant were calculated in average to obtain average square of land per plant. Plant density was calculated based on intraspecies density (nutmeg and coconut, each) and interspecies (nutmeg + coconut). Plant density was obtained through division of plant land area in $100 \mathrm{~m}^{2}$ based sampling area unit which was then converted to ha.

\subsection{Microclimate Characterization}

Measurement was done every seven days during the research period. Microclimate components being measured were as follows:

a) Transmission radiation $\left(\mathrm{T}_{\mathrm{R}}, \mathrm{W} \mathrm{m}^{-2}\right)$, measured using Digital Lux meter (AR813A) which was then converted to total energy per unit area (Watts $\mathrm{m}^{-2}$ ) multiplied by 0.00402 (Thimijan \& Heins, 1983; Anonymous, 2013). 
Measurement was done below the canopy of sample nutmeg plants by placing the instrument at $2 \mathrm{~m}$ above the ground. Period of measurement was from 10.00 to 14.00 with the interval of every two hours $(10.00,12.00$, and 14.00). The instrument was placed half from the plant to the outer canopy in the points of north, south, east, and west. As many as 6 units of lux meters were used at the same time, so that the total time needed in one observation ranged from 4-5 minutes; b) Interception radiation $\left(\mathrm{I}_{\mathrm{R}}, \mathrm{W} \mathrm{\textrm {m } ^ { - 2 }}\right)$, is the proportion of radiation incidence above the canopy with that being transmitted by the canopy to land surface. In this regard, the following equation was used:

$$
\mathrm{I}_{\mathrm{PAR}}=100 \%\left(1-\mathrm{T}_{\mathrm{R}} / \mathrm{i}_{\mathrm{R}}\right)
$$

Where, $i_{R}$ is incidence above the canopy and $T_{R}$ is transmission radiation; which is a radiation transmitted by the canopy to land surface. For incidence above the canopy $\left(i_{R}\right)$, measurement was done in open place (direct sunlight from the sky) by placing Digital Lux meter on $2 \mathrm{~m}$ from surface level, observed at the same period with the observation time of $\mathrm{T}_{\mathrm{R}}$; c) Air temperature $\left({ }^{\circ} \mathrm{C}\right)$ and relative humidity $(\%)$ were observed in daytime along with the observation of solar radiation, using Thermohygrometer (TFA Germany) (as many as 44 unit) being positioned at all sample trees and in the open place at least two hours prior to measurement; d) Rainfall (mm), measured using rain gauge obs placed in the research sites, observed each day during research period at 07.00 am local time.

\subsection{Nutmeg Plant Characteristics}

Nutmeg trees were observed according to the number of individual plants in the plot or sampling unit. Plant characteristics being observed included vegetative and production components as follows: a) Stem diameter (cm), measured at Diameter at Breast Height (DBH $130 \mathrm{~cm}$ ) (Mitchell, 2010), if measurement could not be done at DBH measurement was done in the middle of stem length (van Noordwijk et al., 2002); b) Crown height (m), masured from the point at the first branch up to the tip of the highest branch, using roll meter; c) Canopy width (m), determined based on the projection of tree crown (Pretzsch, 2009) in north-south and east-west sides, using roll meter; d) Sum of branch, determined by counting all primary branches per individual sample nutmeg tree; e) Sum of fruits (fruit tree ${ }^{-1}$ year $^{-1}$ ), determined by the number of harvested fruits per single tree for the period of one year (January-December); the fruits are ready to harvest when the fleshy rind of the nut splits open; f) Weight of dry mace $\left(\mathrm{kg}_{\text {tree }}^{-1}\right.$ year $\left.^{-1}\right)$, along with kernel being measured using analitic balance. $\mathrm{g}$ ) Weight of dry kernel $\left(\mathrm{kg}_{\text {tree }}^{-1}\right.$ year $\left.^{-1}\right)$, is seed flesh without seed coat/shell (dry seed is characterized by noise when seed coat or shell is shaken); h) Edible portion (EP, \% weight), proportion of weight of fleshy to total weight of fruit:

$$
E P=\frac{\text { Fleshy }(g)}{\text { Fleshy }+ \text { Kernel }+\operatorname{Mace}(g)} \times 100
$$

i) To explore the interaction among individual plants in the planting system, Relative Neighbor Effect (RNE) analysis was used based on equation from Markham and Chanway (1996) in Bachmann et al. (2005), Oksanen et al. (2006). RNE was calculated based on the sum of branches per plant and weight of kernel per plant per year, as follows:

$$
\mathrm{RNE}=\left(\mathrm{y}_{-\mathrm{T}}-\mathrm{y}_{+\mathrm{T}}\right) / \mathrm{y}_{\max }
$$

Where, $\mathrm{y}_{-\mathrm{T}}$ is average sum of branch and weight of kernel per year from single nutmeg tree $\left(\mathrm{n}_{1}\right), \mathrm{y}_{+\mathrm{T}}$ is average sum of branch and weight of kernel from nutmeg tree at the plant system of nutmeg + nutmeg $\left(\mathrm{n}_{1} \mathrm{n}_{1}\right)$ and nutmeg + coconut $\left(\mathrm{n}_{1,2,3,4} \mathrm{c}_{1,2,3}\right)$, and $\mathrm{y}_{\max }=$ sum of branch and the highest weight of kernel of individual tree from all planting systems. The value of RNE ranged from -1 to +1 , negative value indicated facilitation and positive indicated competition.

\subsection{Data Analysis}

Results of observation regarding microclimate components and nutmeg plant characteristics from each sampling unit as a response to the plant density in the plant system, were calculated in average to obtain the value per individual plant. Density is the rough measure of competition or interactive part of the population because it is an individual plant which responds to the effect of neighbors, and not the population density (Mack dan Harper, 1977 in Shaukat et al., 2009).

Degree of association between plant density and microclimate and plant characteristics was analyzed using correlation analysis. To estimate contribution of plant density toward microclimate components and nutmeg production components, as well as contribution of microclimate component toward nutmeg production, regression method with stepwise procedures was used (Sarle dan Goodninght, 1982; Wuensch, 2006). Data analysis was performed using SAS ver.9.1 (SAS, 2004). 


\section{Results and Discussion}

\subsection{Plant Density}

Nutmeg plant density was in the range of 47 to 417 tree ha ${ }^{-1}$ dan coconut plant 54 to 335 tree ha $^{-1}$, with average density each accounting for 218 and 144 tree $\mathrm{ha}^{-1}$. Total density (nutmeg + coconut) ranged from 100 to 567 trees $\mathrm{ha}^{-1}$ with average density of 362 trees ha ${ }^{-1}$. Average relative density ratio between nutmeg and coconut is $58: 42 \%$, meaning that nutmeg is more dominant than coconut (Table 1).

Table 1. Plant density of nutmeg and coconut in each planting system

\begin{tabular}{|c|c|c|c|c|c|}
\hline \multirow{2}{*}{ Pair of Plants $(N+C)$} & \multicolumn{3}{|c|}{ Plant Density (tree ha $\left.{ }^{-1}\right)$} & \multicolumn{2}{|c|}{ Relative Density (\%) } \\
\hline & Nutmeg $(\mathrm{N})$ & Coconut (C) & $\mathbf{N}+\mathbf{C}$ & $\mathbf{N}$ & $\mathrm{C}$ \\
\hline $\mathrm{P}_{1}$ & 46.85 & 53.54 & 100.38 & 46.67 & 53.33 \\
\hline $\mathrm{P}_{1} \mathrm{P}_{1}$ & 82.06 & 41.03 & 123.09 & 66.67 & 33.33 \\
\hline $\mathrm{P}_{1} \mathrm{~K}_{1}$ & 58.45 & 87.68 & 146.13 & 40.00 & 60.00 \\
\hline $\mathrm{P}_{1} \mathrm{~K}_{2}$ & 107.02 & 122.31 & 229.34 & 46.67 & 53.33 \\
\hline $\mathrm{P}_{1} \mathrm{~K}_{3}$ & 91.90 & 252.73 & 344.64 & 26.67 & 73.33 \\
\hline $\mathrm{P}_{2} \mathrm{~K}_{1}$ & 149.03 & 99.36 & 248.39 & 60.00 & 40.00 \\
\hline $\mathrm{P}_{2} \mathrm{~K}_{2}$ & 151.50 & 173.15 & 324.65 & 46.67 & 53.33 \\
\hline $\mathrm{P}_{2} \mathrm{~K}_{3}$ & 223.11 & 334.67 & 557.78 & 40.00 & 60.00 \\
\hline $\mathrm{P}_{3} \mathrm{~K}_{1}$ & 274.89 & 99.96 & 374.85 & 73.33 & 26.67 \\
\hline $\mathrm{P}_{3} \mathrm{~K}_{2}$ & 322.50 & 215.00 & 537.49 & 60.00 & 40.00 \\
\hline $\mathrm{P}_{3} \mathrm{~K}_{3}$ & 340.14 & 226.76 & 566.89 & 60.00 & 40.00 \\
\hline $\mathrm{P}_{4} \mathrm{~K}_{1}$ & 417.16 & 104.29 & 521.46 & 80.00 & 20.00 \\
\hline $\mathrm{P}_{4} \mathrm{~K}_{2}$ & 390.85 & 97.71 & 488.57 & 80.00 & 20.00 \\
\hline $\mathrm{P}_{4} \mathrm{~K}_{3}$ & 407.19 & 101.80 & 508.98 & 80.00 & 20.00 \\
\hline
\end{tabular}

Note. $\mathrm{n}_{1}=1$ nutmeg, $\mathrm{n}_{1} \mathrm{n}_{1}=1$ nutmeg +1 nutmeg, $\mathrm{n}_{1} \mathrm{c}_{1}=1$ nutmeg +1 coconut, $\mathrm{n}_{1} \mathrm{c}_{2}=1$ nutmeg +2 coconut, $\mathrm{n}_{1} \mathrm{c}_{3}=1$ nutmeg +3 coconut, $\mathrm{n}_{2} \mathrm{c}_{1}=2$ nutmeg +1 coconut, $\mathrm{n}_{2} \mathrm{c}_{2}=2$ nutmeg +2 coconut, $\mathrm{n}_{2} \mathrm{c}_{3}=2$ nutmeg +3 coconut, $\mathrm{n}_{3} \mathrm{c}_{1}=3$ nutmeg +1 coconut, $\mathrm{n}_{3} \mathrm{c}_{2}=3$ nutmeg +2 coconut, $\mathrm{n}_{3} \mathrm{c}_{3}=3$ nutmeg +3 coconut, $\mathrm{n}_{4} \mathrm{c}_{1}=4$ nutmeg +1 coconut, $\mathrm{n}_{4} \mathrm{c}_{2}=4$ nutmeg +2 coconut, and $\mathrm{n}_{4} \mathrm{c}_{3}=4$ nutmeg +3 coconut.

According to Hadad et al. (2006), planting spacing of monoculture nutmeg is $8 \mathrm{~m} \times 8 \mathrm{~m}, 9 \mathrm{~m} \times 9 \mathrm{~m}$, and $10 \mathrm{~m} \times$ $10 \mathrm{~m}$. This means that in the land size of 1 ha there are 156 plants with the the spacing of $8 \mathrm{~m} \times 8 \mathrm{~m}, 122$ plants with the spacing of $9 \mathrm{~m} \times 9 \mathrm{~m}$, and 100 plants with the spacing of $10 \mathrm{~m} \times 10 \mathrm{~m}$. Based on this planting spacing, nutmeg planting in the research location has high density, namely 218 plants/ha in average. In fact, nutmeg in research location has already 40 years of age, with the canopy width of an individual tree (without canopy intersection with neighboring plants) being $8.77 \mathrm{~m}$ or with diameter of $4.18 \mathrm{~m}$. Therefore, planting spacing of 8 $\mathrm{m} \times 8 \mathrm{~m}$ with population of 156 plants ha ${ }^{-1}$ can make some parts of canopy shadowing each other. The use of the spacing of $10 \mathrm{~m} \times 10 \mathrm{~m}$ leads to inefficiency in the land use because much space has not been utilized. To avoid these two conditions, the spacing of $9 \mathrm{~m} \times 9 \mathrm{~m}$ (population of 122 plants ha ${ }^{-1}$ ) is considered optimum to be used in nutmeg cultivation. When cocount was planted within nutmeg trees with the spacing of $9 \mathrm{~m} \times 9 \mathrm{~m}$, there would be population of coconut of 122 trees $^{-h^{-1}}$. What is important here is the effect of coconut trees as near-neighbors of nutmeg on microclimate and nutmeg production. This will be the subject of further discussion in the following section.

\subsection{Relationship between Plant Density with Microclimate and Nutmeg Characteristics}

Observation results on microclimate components and plant characteritics are summarized in Table 2. Transmitted radiation below the nutmeg tree canopy was in the range of $0.81-2.95 \mathrm{~W} \mathrm{~m}^{-2}$, the highest $\left(2.95 \mathrm{~W} \mathrm{~m}^{-2}\right)$ in the tree without canopy intersection $\left(\mathrm{n}_{1}\right)$ and the lowest $\left(0.81 \mathrm{~W} \mathrm{~m}^{-2}\right)$ in 4 nutmeg +3 coconut $\left(\mathrm{n}_{4} \mathrm{c}_{3}\right)$. The contrary results were found with intercepted radiation, in which the lowest was in $\mathrm{n}_{1}(98.55 \%)$ and the highest $(99.60 \%)$ was in $\mathrm{n}_{4} \mathrm{c}_{3}$ (Table 2). This result indicated that the higher the plant density, the higher the quantity of solar radiation being held by canopy stands, and the lower the solar radiation able to pass down below the crown. In the planting system with 2 to 4 neighboring nutmeg trees, crown was intersectioned each other or canopy stands 
were formed so that the amount of solar radiation transmitted to the lower part of the crown (transmitted radiation) was decreasing.

Table 2. Summary of results of observation regarding microclimate components and plant characteristics in nutmeg and coconut planting system $(\mathrm{N}=42)$

\begin{tabular}{|c|c|c|c|c|}
\hline Variables & Mean & Std. Dev. & Mininimum & Maximum \\
\hline \multicolumn{5}{|l|}{ Microclimate Components } \\
\hline Transmitted radiation $\left(\mathrm{W} \mathrm{m}^{-2}\right)$ & 1.52845 & 0.53131 & 0.81160 & 2.94700 \\
\hline Intercepted radiation (\%) & 99.24571 & 0.26153 & 98.55000 & 99.60000 \\
\hline Temperature $\left({ }^{0} \mathrm{C}\right)$ & 28.28929 & 0.38990 & 27.39000 & 28.98000 \\
\hline Relative Humidity (\%) & 77.89929 & 1.13913 & 76.15000 & 80.87000 \\
\hline \multicolumn{5}{|l|}{ Nutmeg Components } \\
\hline Stem Diameter $(\mathrm{cm})$ & 21.28071 & 1.46034 & 19.17000 & 23.60000 \\
\hline Crown Height (m) & 12.40143 & 1.00131 & 11.09000 & 14.36000 \\
\hline Canopy Width (m) & 7.62071 & 0.84579 & 6.11000 & 8.77000 \\
\hline Sum of Branch & 49.04786 & 10.61598 & 34.67000 & 67.33000 \\
\hline Sum of Fruits (grain tree ${ }^{-1} \mathrm{yr}^{-1}$ )+ & 3.04403 & 0.19248 & 2.71350 & 3.29970 \\
\hline Weight of Mace $\left(\mathrm{kg}\right.$ tree $\left.^{-1} \mathrm{yr}^{-1}\right)$ & 0.96595 & 0.51232 & 0.26490 & 1.73620 \\
\hline Weight of Kernel $\left(\mathrm{kg}\right.$ tree $\left.\mathrm{er}^{-1}\right)$ & 5.29697 & 2.29542 & 1.64830 & 8.57220 \\
\hline Edible Portion (\%) & 82.81286 & 1.85709 & 79.27000 & 85.65000 \\
\hline
\end{tabular}

Note. + observation data were transformed into logarithm.

Statistical analysis showed that nutmeg plant density had very significant negative correlation with transmitted radiation $\left(\mathrm{r}=-0.8287^{* *}\right)$ and temperature $\left(\mathrm{r}=-0.7765^{* *}\right)$, and very significant positive correlation with intercepted radiation $\left(\mathrm{r}=0.8288^{* *}\right)$ and relative humidity $\left(\mathrm{r}=0.7643^{* *}\right)$. There was no correlation between coconut plant density and all microclimate components observed (Table 3). Nutmeg plant density had very significant positive correlation with crown height $\left(\mathrm{r}=0.7769^{* *}\right)$ and very significant negative correlation with stem diameter $(\mathrm{r}=-0.9229)$, sum of branch $\left(\mathrm{r}=-0.9472^{* *}\right)$, canopy width $\left(\mathrm{r}=-0.8051^{* *}\right)$, sum of fruit $(\mathrm{r}=$ $\left.-0.9745^{* *}\right)$, weight of mace $\left(\mathrm{r}=-0.8928^{* *}\right)$, and weight of kernel $\left(\mathrm{r}=-0.9221^{*}\right)$, but had non-significant correlation with edible portion. While coconut plant density was non-significantly correlated with all nutmeg plant characteristics observed (Table 3).

Table 3. Correlation coefficient (r) between plant density, microclimate components, and nutmeg plant charateristics $(\mathrm{N}=42)$

\begin{tabular}{lllllll}
\hline & $\begin{array}{l}\text { Nutmeg } \\
\text { Density }\end{array}$ & $\begin{array}{l}\text { Coconut } \\
\text { Density }\end{array}$ & $\begin{array}{l}\text { Transmitted } \\
\text { Radiation }\end{array}$ & $\begin{array}{l}\text { Intercepted } \\
\text { Radiation }\end{array}$ & Tempera-ture & $\begin{array}{l}\text { Relative } \\
\text { Humadity }\end{array}$ \\
\hline Nutmeg Density & - & $0.1354^{\text {ns }}$ & $-0.8288^{* *}$ & $0.8288^{* *}$ & $-0.7765^{* *}$ & $0.7643^{* *}$ \\
Coconut Density & & - & $-0.2636^{\text {ns }}$ & $0.2666^{\text {ns }}$ & $0.1350^{\text {ns }}$ & $-0.0826^{\text {ns }}$ \\
Stem Diameter & $-0.9229^{* *}$ & $-0.2580^{\text {ns }}$ & - & - & - & - \\
Crown Height & $0.7769^{* *}$ & $-0.0612^{\text {ns }}$ & $-0.7993^{* *}$ & $0.8008^{* *}$ & $-0.8595^{* *}$ & $0.8806^{* *}$ \\
Canopy Width & $-0.8051^{* *}$ & $-0.1084^{\text {ns }}$ & $0.7276^{* *}$ & $-0.7261^{* *}$ & $0.8092^{* *}$ & $-0.7072^{* *}$ \\
Sum of Branch & $-0.9472^{* *}$ & $-0.2434^{\text {ns }}$ & $0.8803^{* *}$ & $-0.8795^{* *}$ & $0.7901^{* *}$ & $-0.7367^{* *}$ \\
Sum of Fruits & $-0.9745^{* *}$ & $-0.0900^{\text {ns }}$ & $0.8446^{* *}$ & $-0.8445^{* *}$ & $0.8150^{* *}$ & $-0.7718^{* *}$ \\
Weight of Mace & $-0.8928^{* *}$ & $0.0998^{\text {ns }}$ & $0.7499^{* *}$ & $-0.7487^{* *}$ & $0.8002^{* *}$ & $-0.7014^{* *}$ \\
Weight of Kernel & $-0.9221^{* *}$ & $-0.0663^{\text {ns }}$ & $0.8388^{* *}$ & $-0.8393^{* *}$ & $0.7894^{* *}$ & $-0.8116^{* *}$ \\
Edible Portion & $0.1351^{\text {ns }}$ & $0.1531^{\text {ns }}$ & $-0 . .1823^{\text {ns }}$ & $0.1875^{\text {ns }}$ & $-0.0985^{\text {ns }}$ & $0.3399^{\text {ns }}$ \\
\hline
\end{tabular}

Note. $\mathrm{ns}=$ not significant and ${ }^{* *}=$ very significant at the level of $\alpha=0.05$. 
Light intensity in mid-day of a sunny day during dry season in Indonesia is in approximately 10,000 foot-candles, and only about $25-30 \%$ of this can be used for photosynthesis by the plants, and even only $10 \%$ in the shadowed parts (Darmawan and Baharsjah, 1983). From the PAR value of a leaf, $10-15 \%$ is not absorbed by photosynthesis pigments but reflected in leaves surfaces or all being transmitted by the leaves, and this transmitted lights is very important for leaves grown under the shadow of other leaves (Taiz \& Zeiger, 1991). Photosynthetic rates at sunlit leaves of tropical trees of Dussia munda and Brosimum utile increased until PAR $1800 \mu \mathrm{mol} \mathrm{m}^{-2} \mathrm{det}^{-1}$, while that of shaded leaves did not increase after reaching PAR $1000 \mu \mathrm{mol} \mathrm{m}^{-2} \operatorname{det}^{-1}$ (Lerdau \& Throop, 2000 in Jennifer \& Lerdau, 2004). This means that a large quantity of radiation being intercepted by nutmeg plant crown due to high plant density, is not an indicator which has linear relationship with the increase in plant productivity; what is important is the distribution of solar radiation which can enter the leaves inside the crown of an individual plant. Light penetration and total interception are only part of the story, and what is also important is the distribution of lights on the leaves (Gutschick, 1997).

Nutmeg plant characteristics, sum of fruits, weight of mace, and weight of kernel had highly significant positive correlation with sum of branch and canopy width, but on the contrary, had highly significant negative correlation with crown height. There was no significant correlation between edible portion and sum of branch, canopy width, crown height, and stem diameter (Table 4). Regression analysis was used to find out the relationship between plant density and microclimate component and nutmeg production, and the results showed that variability of microclimate components (transmitted radiation, intercepted radiation, temperature, relative humidity) and nutmeg plant characteristics (crown height, sum of branches, canopy width, weight of mace, weigth of kernel) could be significantly explained by plant density through linear regression model (Tables 5 and 6 ).

Table 4. Correlation coefficient ( $\mathrm{r}$ ) between vegetative components and production components of nutmeg $(\mathrm{N}=$ 42)

\begin{tabular}{lllll}
\hline & Sum of Fruits & Weight of Mace & Weight of Kernel & Edible Portion \\
\hline Crown Height & $-0.8289^{* *}$ & $-0.7920^{* *}$ & $-0.8273^{* *}$ & $0.4278^{\mathrm{ns}}$ \\
Canopy Width & $0.8052^{* *}$ & $0.7704^{* *}$ & $0.7238^{* *}$ & $-0.0238^{\mathrm{ns}}$ \\
Sum of Branch & $0.9545^{* *}$ & $0.8842^{* *}$ & $0.8883^{* *}$ & $-0.0826^{\mathrm{ns}}$ \\
\hline
\end{tabular}

Note. $\mathrm{ns}=$ not significant and ${ }^{* *}=$ highly significant at the level of $\alpha=0.05$.

Table 5. Summarized stepwise procedure and optimum model of relationship between plant density and microclimate components $(\mathrm{N}=42)$

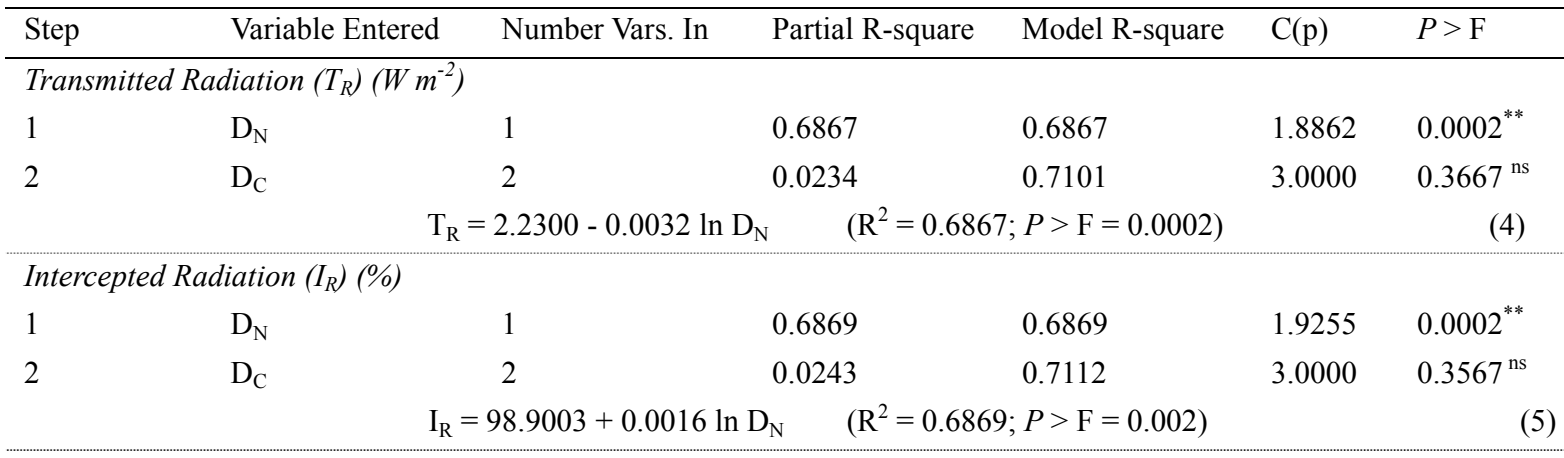

\begin{tabular}{|c|c|c|c|c|c|c|}
\hline \multicolumn{7}{|c|}{ Temperature $(T)(\rho C)$} \\
\hline 1 & $D_{N}$ & 1 & 0.6030 & 0.6030 & 2.9088 & $0.0011^{* *}$ \\
\hline \multirow[t]{2}{*}{2} & $\mathrm{D}_{\mathrm{C}}$ & 2 & 0.0587 & 0.6617 & 3.0000 & $0.1945^{\mathrm{ns}}$ \\
\hline & & $\mathrm{T}=28.7717-0.0022 \ln \mathrm{D}_{\mathrm{N}}$ & \multicolumn{3}{|c|}{$\left(\mathrm{R}^{2}=0.6030 ; P>\mathrm{F}=<0.0011\right)$} & $(6$ \\
\hline \multicolumn{7}{|c|}{ Relative Humidity (RH) (\%) } \\
\hline 1 & $\mathrm{D}_{\mathrm{N}}$ & 1 & 0.5842 & 0.5842 & 2.0197 & $0.0015^{* *}$ \\
\hline \multirow[t]{2}{*}{2} & $\mathrm{D}_{\mathrm{C}}$ & 2 & 0.0353 & 0.6195 & 3.0000 & $0.3343^{\mathrm{ns}}$ \\
\hline & & \multicolumn{5}{|c|}{$\mathrm{RH}=76.5120+0.0063 \ln \mathrm{D}_{\mathrm{N}} \quad\left(\mathrm{R}^{2}=0.5842 ; P>\mathrm{F}=<0.0015\right)$} \\
\hline
\end{tabular}

Note. $\mathrm{D}_{\mathrm{N}}=$ Nutmeg Plant Density $\left(\right.$ tree ha $\left.{ }^{-1}\right), \mathrm{D}_{\mathrm{c}}=$ Coconut Plant Density $\left(\right.$ tree $\left.\mathrm{ha}^{-1}\right) . \mathrm{ns}=$ not significant and ${ }^{* *}=$ highly significant at the level of $\alpha=0.05$. Variables with $P>\mathrm{F}=>0.05$ were not included in the model. 
Table 6. Summarized Stepwise Procedure and optimum model of the relationship between plant density and plant characteristics of nutmeg $(\mathrm{N}=42)$

\begin{tabular}{|c|c|c|c|c|c|c|}
\hline Step & Variable Entered & Number Vars. In & Partial R-square & Model R-square & $C(p)$ & $P>\mathrm{F}$ \\
\hline \multicolumn{7}{|c|}{ Crown Height $\left(C_{h t}\right)(m)$} \\
\hline 1 & $\mathrm{D}_{\mathrm{N}}$ & 1 & 0.6035 & 0.6035 & 1.8423 & $0.0011^{* *}$ \\
\hline \multirow[t]{2}{*}{2} & $\mathrm{D}_{\mathrm{C}}$ & 2 & 0.0282 & 0.6317 & 3.0000 & $0.3784^{\mathrm{ns}}$ \\
\hline & & \multicolumn{2}{|c|}{$C_{h t}=11.1620+0.0057 \ln D_{N}$} & \multicolumn{2}{|c|}{$\left(\mathrm{R}^{2}=0.6035 ; P>\mathrm{F}=0.0011\right)$} & (8) \\
\hline \multicolumn{7}{|c|}{ Sum of Branch $\left(S_{b h}\right)$} \\
\hline 1 & $\mathrm{D}_{\mathrm{N}}$ & 1 & 0.8971 & 0.8971 & 2.6619 & $<0.0001^{* *}$ \\
\hline \multirow[t]{2}{*}{2} & $\mathrm{D}_{\mathrm{C}}$ & 2 & 0.0135 & 0.9106 & 3.0000 & $0.2238^{\mathrm{ns}}$ \\
\hline & & \multicolumn{2}{|c|}{$\mathrm{S}_{\mathrm{bh}}=65.0689-0.0732 \ln \mathrm{D}_{\mathrm{N}}$} & \multicolumn{2}{|c|}{$\left(\mathrm{R}^{2}=0.8971 ; P>\mathrm{F}=<0.0001\right)$} & (9) \\
\hline \multicolumn{7}{|c|}{ Canopy Width $\left(C_{w h}\right)(m)$} \\
\hline 1 & $\mathrm{D}_{\mathrm{N}}$ & 1 & 0.6481 & 0.6481 & 1.0000 & $0.0005^{* *}$ \\
\hline \multirow[t]{2}{*}{2} & $\mathrm{D}_{\mathrm{C}}$ & 2 & - & - & - & $>0.5000^{\mathrm{ns}}$ \\
\hline & & \multicolumn{2}{|c|}{$\mathrm{C}_{\mathrm{wh}}=8.7057-0.0050 \ln \mathrm{D}_{\mathrm{N}}$} & \multicolumn{2}{|c|}{$\left(\mathrm{R}^{2}=0.6481 ; P>\mathrm{F}=0.0005\right)$} & (10) \\
\hline \multicolumn{7}{|c|}{ Sum of Fruits $\left(S_{f s}\right)$ (grain tree $\left.{ }^{-1} y r^{-1}\right)$} \\
\hline 1 & $\mathrm{D}_{\mathrm{N}}$ & 1 & 0.9497 & 0.9497 & 1.4067 & $<0.0001^{* *}$ \\
\hline \multirow[t]{2}{*}{2} & $\mathrm{D}_{\mathrm{C}}$ & 2 & - & - & - & $>0.5000^{\mathrm{ns}}$ \\
\hline & & \multicolumn{2}{|c|}{$\mathrm{S}_{\mathrm{fs}}=1963.7511-3.4478 \ln \mathrm{D}_{\mathrm{N}}$} & \multicolumn{2}{|c|}{$\left(\mathrm{R}^{2}=0.9497 ; P>\mathrm{F}=<0.0001\right)$} & (11) \\
\hline \multicolumn{7}{|c|}{ Weight of Mace $\left(W_{\text {me }}\right)\left(\mathrm{kg}\right.$ tree $\left.^{-1} \mathrm{yr}^{-1}\right)$} \\
\hline 1 & $\mathrm{D}_{\mathrm{N}}$ & 1 & 0.7971 & 0.7971 & 4.5589 & $<0.0001^{* *}$ \\
\hline \multirow[t]{2}{*}{2} & $\mathrm{D}_{\mathrm{C}}$ & 2 & 0.0496 & 0.8467 & 3.0000 & $0.0859^{\mathrm{ns}}$ \\
\hline & & \multicolumn{2}{|c|}{$\mathrm{W}_{\mathrm{me}}=1.6948-0.0033 \ln \mathrm{D}_{\mathrm{N}}$} & \multicolumn{2}{|c|}{$\left(\mathrm{R}^{2}=0.7971 ; P>\mathrm{F}=<0.0001\right)$} & (12) \\
\hline \multicolumn{7}{|c|}{ Weight of Kernel $\left(W_{k}\right)\left(\mathrm{kg}\right.$ tree $\left.{ }^{-1} \mathrm{yr}^{-1}\right)$} \\
\hline 1 & $\mathrm{D}_{\mathrm{N}}$ & 1 & 0.8503 & 0.8503 & 1.2630 & $<0.0001^{* *}$ \\
\hline \multirow[t]{2}{*}{2} & $\mathrm{D}_{\mathrm{C}}$ & 2 & - & - & - & $>0.5000^{\mathrm{ns}}$ \\
\hline & & \multicolumn{2}{|c|}{$\mathrm{W}_{\mathrm{kl}}=8.6696-0.0154 \ln \mathrm{D}_{\mathrm{N}}$} & $=0.8503 ; P>\mathrm{F}=$ & $0.0001)$ & (13) \\
\hline
\end{tabular}

Note. $\mathrm{D}_{\mathrm{N}}=$ Nutmeg Density $\left(\right.$ tree $\left.\mathrm{ha}^{-1}\right), \mathrm{D}_{\mathrm{c}}=$ Coconut Density $\left(\right.$ tree ha $\left.{ }^{-1}\right) . \mathrm{ns}=$ not significant and ${ }^{* *}=$ highly significant at the level of $\alpha=0.05$. Variables with $P>\mathrm{F}=>0.05$ were not included in the model.

In addition to solar radiation, temperature and air humidity also have significant correlation with vegetative and production components of nutmeg (Table 3). Sun radiation transmitted and intercepted by the canopy determines temperature and humidity below the plant canopy. Air temperature below the canopy is decreasing along with the increase in plant density (Table 5, Equation 6); on the contrary, air humidity increases as plant density increases (Table 5, Equation 7). Air temperature and humidity in nutmeg agroecosystem are in the range of 27 to $29^{\circ} \mathrm{C}$ and 76 to $81 \%$, respectively (Table 2). These ranges of air temperature and relative humidity are suitable for the growth of nutmeg. Nutmeg plant grows well (suitable) in the air temperature of 25 to $28^{\circ} \mathrm{C}$ and humidity of 60 to $85 \%$ (Rosman et al., 1989; Orwa et al., 2009).

Nutmeg plant density significantly contributed to transmitted radiation, intercepted radiation, temperature, and relative humidity (Table 5). Plant density of nutmeg contributed significantly to crown weight, sum of branches, canopy width, sum of weight of mace, and weight of kernel, except for edible portion (Tabel 6). Tables 5 and 6 also showed that plant density of coconut did not significantly contributed to microclimate components (partial $\left.\mathrm{R}^{2}=0.0243-0.0587 ; P>\mathrm{F}=0.3667-0.1945\right)$ (Table 5) and nutmeg plant characteristics (partial $\mathrm{R}^{2}=0.0135$ $0.0499 ; P>\mathrm{F}=0.5000-0.0859$ ) (Table 6). The decrease of transmitted radiation and the increase of intercepted radiation along with the increase of nutmeg plant density (Table 5, Equations 4 and 5). In high density condition, photosynthesis from shadowed leaves is not optimum so that there are leaves being parasitic to photosynthate produced by other leaves. One of the impact was that the amount of fotosintat being translocated for the forming of reproductive parts became lower, as had been shown by sum of fruits, weight of mace, and weight of kernel, which tended to decrease along with the increase of plant density of nutmeg (Table 6, Equations 11, 12, and 13). Coconut tree canopy intercepted solar radiation about $64.23 \%$ in average, or transmitted radiation being $35.77 \%$ 
(observation data were not presented). Coconut plant density has insignificant correlation with microclimate component and plant characteristics of nutmeg (Table 3). Coconut plant density also contributed insignificantly to microclimate components $\left(\mathrm{R}^{2}=2.34-5.87 \% ; P>\mathrm{F}=>0.05\right)$ and nutmeg plant characteristics $\left(\mathrm{R}^{2}=1.35-\right.$ $4.96 \% ; P>\mathrm{F}=>0.05$ ) (Table 5 and 6 ), indicating that variability of microclimate and nutmeg plant characteristics was not insignificantly affected by plant density of coconut. This means that decreasing productivity of nutmeg as shown by decreasing tendency of sum of fruits, weight of mace and weight of kernel (Table 6), and not because of the presence of coconut trees in the nearest neighbors, but caused more by the effect of shading of nutmeg with other nutmeg as a result of close distance of neighboring plants.

Plant canopy is dynamic and keeps changing throughout the time in accordance with environmental conditions as canopy is the real form of the plant expression toward its ecosystem and its response with respect to configuration of distance between plants (Tomlinson, 1983; Campbell \& Norman, 1998). Crown shape of nutmeg tree is cylindrical, semi-circular, or piramidal, as a form of adaptation toward its growth environment. Therefore, intersection between plant crown in close planting spacing generally occurs from the crown in central part to the lower part. This condition causes branches in closer sides among the trees become dead, or with the lower number and smaller size when still growing. Sum of branch and canopy width had highly significant and negative correlation with plant density of nutmeg (Table 3), indicating that sum of branch and canopy width decreased as plant density of nutmeg increased (Table 5, Equations 9 and 10). There were positive and highly significant correlation between sum of branch and sum of fruits $(r=0.9545)$, weight of mace $(r=0.8842)$, and weight of kernel $(r=0.8883)$; the same results applied between canopy width and sum of fruits $(r=0.8052)$, weight of mace $(r=0.7704)$, and weight of kernel $(r=0.7238)$ (Table 4). In single nutmeg plant without intersection of crown with neighboring nutmeg plants or without intersection with coconut trees, sum of branch was higher and canopy being wider providing more spaces for the development of fruits (data were not shown).

\subsection{Indication of Competition}

Analysis of the relative neighbor effect based on the indicator of sum of branch and weight of kernel showed that all planting system indicated competition among plants, except for single nutmeg tree (Table 7).

Table 7. Relative Neighbor Effect (RNE) according to sum of branch and weight of kernel

\begin{tabular}{lll}
\hline Pair of Plants $(\mathrm{N}+\mathrm{C})$ & \multicolumn{2}{c}{ RNE } \\
\cline { 2 - 3 } & Sum of Branch & Weight of Kernel \\
\hline $\mathrm{n}_{1}$ & 0.000 & 0.000 \\
$\mathrm{n}_{1} \mathrm{n}_{1}$ & +0.063 & +0.034 \\
$\mathrm{n}_{1} \mathrm{c}_{1}$ & +0.132 & +0.092 \\
$\mathrm{n}_{1} \mathrm{c}_{2}$ & +0.174 & +0.090 \\
$\mathrm{n}_{1} \mathrm{c}_{3}$ & +0.137 & +0.043 \\
$\mathrm{n}_{2} \mathrm{c}_{1}$ & +0.295 & +0.290 \\
$\mathrm{n}_{2} \mathrm{c}_{2}$ & +0.232 & +0.236 \\
$\mathrm{n}_{2} \mathrm{c}_{3}$ & +0.342 & +0.316 \\
$\mathrm{n}_{3} \mathrm{c}_{1}$ & +0.400 & +0.448 \\
$\mathrm{n}_{3} \mathrm{c}_{2}$ & +0.353 & +0.480 \\
$\mathrm{n}_{3} \mathrm{c}_{3}$ & +0.490 & +0.491 \\
$\mathrm{n}_{4} \mathrm{c}_{1}$ & +0.463 & +0.634 \\
$\mathrm{n}_{4} \mathrm{c}_{2}$ & +0.447 & +0.659 \\
$\mathrm{n}_{4} \mathrm{c}_{3}$ & +0.516 & +0.667 \\
\hline
\end{tabular}

Note. Positive value (+) indicates competition, and zero (0) means no competition and facilitation. $\mathrm{n}_{1}=1$ nutmeg, $\mathrm{n}_{1} \mathrm{n}_{1}=1$ nutmeg +1 nutmeg, $\mathrm{n}_{1} \mathrm{c}_{1}=1$ nutmeg +1 coconut, $\mathrm{n}_{1} \mathrm{c}_{2}=1$ nutmeg +2 coconut, $\mathrm{n}_{1} \mathrm{c}_{3}=1$ nutmeg +3 coconut, $\mathrm{n}_{2} \mathrm{c}_{1}=2$ nutmeg +1 coconut, $\mathrm{n}_{2} \mathrm{c}_{2}=2$ nutmeg +2 coconut, $\mathrm{n}_{2} \mathrm{c}_{3}=2$ nutmeg +3 coconut, $\mathrm{n}_{3} \mathrm{c}_{1}=3$ nutmeg +1 coconut, $\mathrm{n}_{3} \mathrm{c}_{2}=3$ nutmeg +2 coconut, $\mathrm{n}_{3} \mathrm{c}_{3}=3$ nutmeg +3 coconut, $\mathrm{n}_{4} \mathrm{c}_{1}=4$ nutmeg +1 coconut, $\mathrm{n}_{4} \mathrm{c}_{2}=4$ nutmeg +2 coconut, and $\mathrm{n}_{4} \mathrm{c}_{3}=4$ nutmeg +3 coconut.

It has been described previously that decreasing nutmeg production was caused more by interaction among nutmeg trees, not by the presence of coconut trees as nearest-neighbors. This indicated the occurence of 
intraspecific competition (nutmeg and nutmeg), not interspecific (nutmeg and coconut). Competitive interaction where growth of individual plant is reduced by the presence of neighboring plants has been proven in many researches (Lavigne, 1988; Frank, 1990; Jobidon, 1994; Umeki, 1995; Takahashi, 1996 in Duchesneau et al., 2001). Indication of intraspecific competition between near-neighboring nutmeg and nutmeg in planting system of 2-3-4 pairs of plants was represented by sum of branch and weight of kernel (Table 7). It is apparent that competition indication increases with the increase in the number of plants that are near-neighboring or increased nutmeg plant density. In intersection of crown 1 nutmeg +1 nutmeg, RNE value is +0.063 increasing to +0.516 in 4 nutmeg for the indicator of sum of branch, and +0.034 increasing to +0.667 for weight of kernel. These two indicators (sum of branch and weight of fruits) had highly significant and positive correlation $\left(r=0.8883^{* *}\right)$ (Table 4), and both had highly significant and negative correlation with nutmeg plant density $\left(r=-0.9472^{* *}\right.$ and $-0.9221,{ }^{* *}$ respectively) (Table 3 ). This meant that nutmeg being planted with too close planting distance exceeding optimum spacing or plant density would cause sum of branch to decrease which in turn would lead to decreased total weight of fruit per an individual tree per period of time.

The above descriptions suggested that interactions among near-neighboring plants where plant density has exceeded its optimum level had become one of the reasons for the intraspecific competition. It has been shown that the quantity of radiation energy penetrating the canopy (represented by transmitted radiation) was one of the factors determining nutmeg production. Duchesneau et al. (2001) confirmed previous findings of Chazdon (1988) that under certain ranges of wavelength, the effect of light on the growth is much stronger than many other biotic and abiotic factors, including competition. Therefore, planting spacing of nutmeg is important to enable optimum conditions for the distribution of radiation energy, temperature and relative humidity in the plant canopy. Mixed planting of nutmeg with coconut provided double advantages, namely in spatial aspect (more efficient land utilization - one unit of land with two types of plants) and in economic aspect, namely farmers being able to harvest both nutmeg and coconut.

\section{Conclusion}

1) Plant density of nutmeg in the research location has exceeded optimum population. Optimum plant density is expected to occur at the population of 122 plants $^{-1} \mathrm{a}^{-1}$ in the planting space of $9 \mathrm{~m} \times 9 \mathrm{~m}$.

2) Intersection between crown of nutmeg in high plant density made radiation being transmitted and temperature decreasing, whereas intercepted radiation and relative humidity were increasing. This further led to decrease in the sum of fruits, weight of mace, and weight of kernel of nutmeg.

3) Plant density of coconut did not have significant correlation with - and not insignificantly contributed to components of microclimate and nutmeg production. For this reason, coconut can be cultivated in mixed planting with nutmeg.

4) Mixed planting of nutmeg with coconut can be applied each with the spacing of $9 \mathrm{~m} \times 9 \mathrm{~m}$ (population of 122 trees ha ${ }^{-1}$ each), where coconut is placed among nutmeg trees. In Wakatobi district, in such spacing and plant density, until the age of 40 years crown of a nutmeg tree touched the crown of other nutmeg trees but not shading each other.

\section{References}

Abdul, M., \& Tjokrodingrat, S. (2013). Kajian dan pilot pengembangan tanaman pala di Kabupaten Wakatobi. Pemda Kabupaten Wakatobi - CV. Tirta Arta Consulindo (p. 60). Tidak dipublikasi.

Anandaraj, M., Devasahayam, S., Zachariah, T. J., Krishnamoorthy, B., Mathew, P. A., \& Rema, J. (2005). Nutmeg (extension pamphlet). In P. Rajeev \& N. K. Leela (Ed.), Indian Inst. of Spices Res (pp. 1-7). Casle, Kochi.

Anonymous. (2013). Light measurement guidance notes (p. 13). Skye instrument Ltd. Retrieved June 17, 2013, from http://upgmbh.comfileadminsupportpdfLightGuidanceNotes.pdf-17-6-2013

Bachmann, U., Hensen, I., \& Partzsch, M. (2005). Is Campanula glomerata threatened by competition of expanding grasses? Plant Ecol., 180, 257-265. http://dx.doi.org/10.1007/s11258-005-3788-0

Campbell, G. S., \& Norman, J. M. (1998). An introduction to environmental biophysics (2nd ed., p. 306). Springer-Verlag, NY, Inc. http://dx.doi.org/10.1007/978-1-4612-1626-1

Darmawan, J., \& dan Baharsjah, J. (1983). Dasar-dasar ilmu fisiologi tumbuhan (p. 93). PT. Suryandaru, Semarang.

Duchesneaua, R., Lesagea, I., Messierb, C., \& Morin, H. (2001). Effects of light and intraspecific competition on growth and crown morphology of two size classes of understory balsam fir saplings. Forest Ecol. \& 
Manag., 140, 215-225. http://dx.doi.org/10.1016/S0378-1127(00)00281-4

Gutschick, V. P. (1997). Photosynthesis, growth rate, and biomass allocation. In L. E. Jackson (Ed.), Ecology in Agriculture (pp. 39-78). Academic Press, N.Y. http://dx.doi.org/10.1016/b978-012378260-1/50003-8

Hadad, E. A., \& dan Hamid, A. (2009). Mengenal berbagai plasma nutfah pala di daerah Maluku Utara. Prosiding Simposium I Hasil Penelitian dan Pengembangan Tanaman Industri (Vol. 8, pp. 1213-1222). Puslibangtan Industri, Bogor.

Hadad, E. A., \& dan Syakir, M. (1992). Pengadaan bahan tanaman pala. Perkembangan Penelitian Tanaman Pala dan Kayumanis. Edisi Khusus Penelitian Tanaman Rempah dan Obat, Balitro (Vol. 8, Issue 1, pp. 1-7). Bogor.

Hadad, E. A., Lukman, W., Sudrajat, D., Nurawan, A., Iskandar, T., \& dan Bachmid, S. (1996). Keragaman tanaman pala di kebun koleksi ex situ Bacan Maluku Utara. Prosiding Seminar Hasil Penelitian Plasma Nutfah Pertanian (pp. 213-223). Badan Litbangtan.

Hadad, E. A., Randriani, E., Firman, C., \& dan Sugandi, T. (2006). Budidaya Pala (p. 38). Balai Tanaman Rempah dan Aneka Tanaman Industri, Parungkuda.

Jennifer, L. F., \& Lerdau, M. T. (2004). Photosynthesis in Forest Canopies. In M. D. Lowman \& H. B. Rinker (Eds.), Forest canopies (pp. 335-358). Elsevier Inc. London.

Jose, S., Gillespie, A. R., \& Pallardy, S. G. (2004). Interspecific interactions in temperate agroforestry. Agroforest. Sys., 61, 237-255. http://dx.doi.org/10.1007/978-94-017-2424-1_17

Krishnamoorthy, B., \& Rema, J. (2001). Nutmeg and mace. In K. V. Peter (Ed.), Handbook of herbs and spices (pp. 238-260). Woodhead Pub. Ltd, Cambridge England. http://dx.doi.org/10.1533/9781855736450.238

Leela, N. K. (2008). Nutmeg and mace. In V. A. Parthasarathy, B. Chempakam, \& T. J. Zachariah (Eds.), Chemistry of spices (pp. 165-189). CAB Int. London, UK. http://dx.doi.org/10.1079/9781845934057.0165

Mark, A. F., \& Esler, A. E. (1970). Proceedings of the new zealand an assessment of the point-centred quarter method of plotless sampling in some New Zealand forests. Proc. of the New Zealand Ecol. Society, 17, 106-110.

Marzuki, I., Hadad, E. A., Syukur, M., \& dan Assegaf, M. (2006). Potensi dan pengembangan pala di Maluku Utara (p. 57). Balittro. Bogor.

May, A. B., \& Penfound, W. M. T. (1967). EHiciencies of the point.cent.red quarter and quadrat methods in forest sampling. Proc. of the Okla. Acad. of Sci. For. (pp. 6-10).

Mitchell, K. (2010). Quantitative Analysis by the point-centered quarter method (p. 34). Dep. of Math. \& Comp. Sci. Hobart \& William Smith Colleges. Geneva, NY.

Oksanen, L., Sammul, M., \& Magi, M. (2006). On the indices of plant-plant competition and their pitfalls. Oikos., 112, 149-155. http://dx.doi.org/10.1111/j.0030-1299.2006.13379.x

Orwa, C., Mutua, A., Kindt, R., Jamnadass, R., \& Simons, A. (2009). Agroforestree Database: A tree reference and selection guide version 4.0. Retrieved July 7, 2011, from http:// worldagroforestry.org/af/treedb

Pretzsch, H. (2009). Forest dynamics, growth and yield: From measurement to model (p. 671). Springer-Verlag Berlin Heidelberg. http://dx.doi.org/10.1007/978-3-540-88307-4_1

Rosman, R., Emmyzar, \& dan Tasma, M. (1989). Studi kesesuaian lahan dan iklim tanaman pala (Myristica fragrans). Balitro, Bogor.

Sarle, S. W., \& Goodninght, J. H. (1982). The R-square procedure. In A. A. Ray (Ed.), SAS User's Guide (pp. 86-91). Stat. SAS Inst. Inc. Cary, NC.

SAS Institute. (2004.) SAS/STAT User's Guide (Release 9.1.3 ed.). SAS Institute Inc. Cary, NC.

Shaukat, S. S., Ahmed, W., Khan, M. A., \& Shahzad, A. (2009). Intraspecific competition and aggregation in a population of Solanum forskalii Dunal in a semiarid habitat: Impact on reproductive output, growth and phenolic contents. Pak. J. Bot., 41(6), 2751-2763.

Taiz, L., \& Zeiger, E. (1991). Plant physoilogy (p. 591). The Benjamin/Cummings Pub. Co., Inc. Redwood City, California.

Thimijan, R. W., \& Heins, R. D. (1983). Photometric, radiometric, and quantum light units of measure: A review of procedures for interconversion. HortSci., 18(6), 5. 
Tomlinson, P. B. (1983). Tree architecture: New approaches help to define the elusive biological property of tree form. Amer. Sci., 71(2), 141-149.

Van Noordwijk, M., Mulia, R., \& dan Hairiah, K. (2002). Estimasi biomasa tajuk dan akar pohon dalam sistem agroforestri: Analisis cabang fungsional (functional branch analysis, FBA) untuk membuat persamaan alometrik pohon. In K. Hairiah, S. R. Utami \& dan B. Lusiana (Ed.), WaNuLCAS model simulasi untuk sistem agroforestri (pp.137-152). ICRAF Sea Region. Res. Prog. Bogor.

Wahyuni, S., Hadad, E. A., \& Suparman, dan M. (2008). Keragaman produksi plasma nutfah pala (Myristica fragrans) di KP Cicurug. Bul. Plasma Nutfah., 14(2), 68-75.

Wardiana, E., Randriani, E., \& dan Tresniawati, C. (2008). Seleksi beberapa karakter penting 15 aksesi tanaman pala (Myristica fragrans Houtt.) di kebun percobaan Cicurug, Sukabumi. Zuriat., 19(1), 116-129.

Wuensch, K. L. (2006). Stepwise multiple regression. Retrieved February 19, 2011, from http://core.ecu.edu/psyc/wuenschk/MV/multReg/Stepwise.doc

\section{Copyrights}

Copyright for this article is retained by the author(s), with first publication rights granted to the journal.

This is an open-access article distributed under the terms and conditions of the Creative Commons Attribution license (http://creativecommons.org/licenses/by/3.0/). 